\title{
Identification of the technical product characteristics of process scoping studies
}

\author{
Alexander Feofanov ${ }^{1, *},{\text { Natal'ja } \mathrm{Kim}^{2}, \text { Evgenij Frolov }}^{1}$, and Tat'jana Grishina ${ }^{1}$ \\ ${ }^{1}$ Moscow State University of «STANKIN», 127055, 1, Vadkovsky per., Moscow, Russian Federation \\ 2 OOO "OMS Management", 143441,69 km MKAD str., 15, Krasnogorsk district, Moscow region, Russian Federation
}

\begin{abstract}
The analysis of methods for converting customer requirements into optimal technical characteristics of the product was made, a conclusion was made about the applicability of the methodology for the deployment of quality functions. Deficiencies in methodology have been identified and a decision has been made about the need to apply the principles of the method of analyzing hierarchies and expert assessments within the methodology of the deployment of quality functions. Presented organizationalmethodical provision of the process for identifying the technical product characteristics for the purpose of optimization of process scoping studies. The technique of identification of technical characteristics of a product is offered. Expert groups were identified in the context of the processes stages of identifying technical characteristics of the product, principles for the formation of priority matrices were recognized. Reviewed the application of techniques based decision support system with three-level data store.
\end{abstract}

In the conditions of a dynamically changing market and in order to support the state program "Development of Industry and Enhancing Its Competitiveness" in the development and application of advanced industrial technologies, in particular information technologies, most enterprises of the machine-building complex are aimed at developing and expanding the sales market. The goal can be achieved by minimizing the error at the design stage of the product and its pre-project research by identifying those technical characteristics of the product whose target indicators affect the demand of consumers.

Based on the findings, it was decided to optimize the stage of pre-project research by developing a system of models and a technique for identifying technical characteristics.

The most reliable method for converting customer requirements into optimal product specifications is the methodology for the deployment of quality functions $[1,2]$. The idea of deploying quality functions appeared in Japan in the late 1960s. The first book, "Deploying Quality Functions," was written by Prof. Shigeru Mizuno and Yohji Akao and published in Japan in 1978 [3].

The disadvantage of the method is an unregulated procedure for making interim and final decisions [4,5].

In order to regulate the decision-making processes, the hierarchy analysis method (MAI) was analyzed. MAI is a mathematical tool for a systematic approach to complex decision-making problems. The method was developed by the American mathematician Thomas Saati, his first works about the method were published in American scientific journals since 1979 [6].
The disadvantage of the method is the probability of mismatched estimates in the case of an incorrectly formed expert group [7,8].

The analysis of modern mechanisms for the formation of expert groups made it possible to determine the mechanism for evaluating potential experts with the aim of forming expert groups. Based on the conducted research, applying the principles of MAI, curly RFK matrix can be represented as a graph hierarchy structure (Fig. 1) [9].

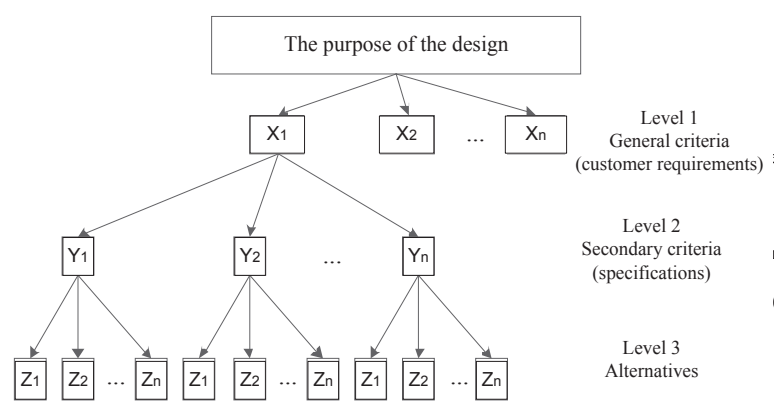

Fig. 1. Interpretation of the figured matrix of the RQF methodology in the form of a graph.

The picture mentions one branch of the graph, showing the relationship of customer X1 requirements with technical specifications and alternatives in achieving the design goals.

The system of models for identification of the product's technical characteristics at the stage of its design is based on the methodology of the RFK taking into account the principles of the MIA and methods of expert assessments [10].

\footnotetext{
* Corresponding author: feofanov.fan1@yandex.ru
} 
Based on the proposed system of models, a technique for identifying product specifications (MITCI) was developed. To carry out subjective paired comparisons, based on the hierarchy analysis method, for evaluation experts are guided by a scale of relative importance (Table 1) [6].

Table 1. Scale of relative importance

\begin{tabular}{|c|c|c|}
\hline $\begin{array}{l}\text { Degr } \\
\text { ee of } \\
\text { prefer } \\
\text { ence }\end{array}$ & Definition & Comments \\
\hline 0 & Incomparable & $\begin{array}{l}\text { The expert finds it difficult to } \\
\text { compare }\end{array}$ \\
\hline 1 & $\begin{array}{l}\text { Equal } \\
\text { importance }\end{array}$ & $\begin{array}{l}\text { Equal contribution of the two } \\
\text { types of activities in goal }\end{array}$ \\
\hline 3 & $\begin{array}{l}\text { A moderate } \\
\text { superiority of } \\
\text { one over the } \\
\text { other }\end{array}$ & $\begin{array}{l}\text { Experience and judgment give } \\
\text { the effortless superiority of } \\
\text { one activity over another }\end{array}$ \\
\hline 5 & $\begin{array}{lr}\text { A } & \text { significant } \\
\text { or } & \text { strong } \\
\text { superiority }\end{array}$ & $\begin{array}{l}\text { Experience and judgment give } \\
\text { strong superiority of one type } \\
\text { of activity over another }\end{array}$ \\
\hline 7 & $\begin{array}{l}\text { A significant } \\
\text { advantage }\end{array}$ & $\begin{array}{l}\text { One type of activity is given } \\
\text { so strong superiority that it } \\
\text { becomes } \\
\text { significant }\end{array}$ \\
\hline 9 & $\begin{array}{l}\text { Very strong } \\
\text { superiority }\end{array}$ & $\begin{array}{l}\text { The evidence of the } \\
\text { superiority of one type of } \\
\text { activity over another is } \\
\text { confirmed most strongly }\end{array}$ \\
\hline $\begin{array}{l}2,4 \\
6,8\end{array}$ & $\begin{array}{l}\text { Intermediate } \\
\text { solutions } \\
\text { between two } \\
\text { adjacent } \\
\text { judgments }\end{array}$ & Apply in compromise case \\
\hline
\end{tabular}

A scale of relative importance makes it possible to display a number of qualitative results of comparisons to quantitative indicators. Experts form priority matrices, which they fill with respect to the main goal for each customer requirement, product technical specification and alternative (enterprise competitors) [11].

The opinions of several experts are taken into account of the following ways:

- geometric mean;

- Calculation taking into account the qualification of the expert.

In order to take into account the opinions of several experts having equal weight, it is used the geometric mean calculated by the following formula

$$
a_{i j}^{a \text { гр }}=\sqrt[n]{a_{i j}^{(1)} \times a_{i j}^{(2)} \times \ldots \times a_{i j}^{(n)}}
$$

$a_{i j}^{(k)}$ - evaluation of the element belonging to the i-th row and the $\mathrm{j}$-th column of the matrix of paired comparisons of the $\mathrm{k}$-th expert.

This criterion is applicable in view of the following statement: if two experts with an equilibrium opinion designate the estimates of $a$ and $1 / a$ when comparing objects, which in calculating the aggregated estimate gives unity and indicates the equivalence of the compared objects. In the event that the opinions of experts are unequal, the experts' judgment is averaged taking into account their qualifications. To determine the weighting coefficients of experts, use the hierarchical structure of the criteria presented in (Fig. 2).

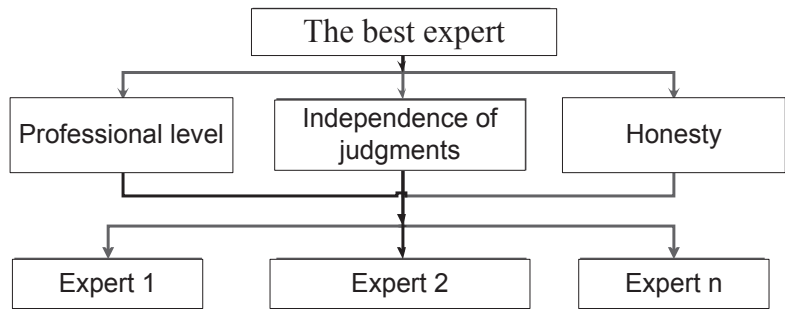

Fig. 2. Hierarchy of the ranking of experts

The calculation of the aggregated estimates in the case involving $\mathrm{n}$ experts, having different significance, is calculated as follows:

$$
a_{i j}^{a z p}=\sqrt[n]{a_{i j}^{\left(\alpha_{1}\right)} \times a_{i j}^{(\alpha 2)} \times \ldots \times a_{i j}^{(\alpha n)}}
$$

$a_{i j}^{\left(\alpha_{k}\right)}$ - the object evaluation, conducted by the k-th expert with weight coefficients $\alpha_{\underline{k}}$.

Herewith $\sum_{k=1}^{n} \alpha_{k}=1$

That is, the equality is valid:

$$
a_{i j}^{\left(\alpha_{1}\right)}=\alpha_{1} a_{i j}^{(1)}
$$

Based on the analysis of scientific works on the problem of forming expert groups and assessing the opinions of experts, it can be concluded that the criterion for assessing the competence of experts is not always applicable, because the effectiveness of the expert depends more on the interest in the results of work, in good faith attitude to work than from the values of the competence factors of experts.

Within MITHI it is recommended to distinguish the components of the expert group in accordance with the stages MITHI (Table 2) [12].

Table 2. The expert group in the framework of MITHI

\begin{tabular}{|c|l|l|}
\hline № & $\begin{array}{c}\text { Position of the } \\
\text { staff members of } \\
\text { the expert group }\end{array}$ & \multicolumn{1}{|c|}{ Process } \\
\hline 1 & $\begin{array}{l}\text { Analyst, } \\
\text { marketer }\end{array}$ & $\begin{array}{l}\text { Definition of the list of require- } \\
\text { ments of the customer }\end{array}$ \\
\hline 2 & $\begin{array}{l}\text { Engineer-designer, } \\
\text { marketer, analyst }\end{array}$ & Ranking of customer requirements \\
\hline 3 & Engineer-designer, & $\begin{array}{l}\text { Definition of technical character- } \\
\text { istics, assignment of local priori- } \\
\text { ties }\end{array}$ \\
\hline 4 & $\begin{array}{l}\text { Engineer-designer, } \\
\text { economist, analyst }\end{array}$ & $\begin{array}{l}\text { Assessment of organizational } \\
\text { complexity }\end{array}$ \\
\hline 5 & $\begin{array}{l}\text { Representatives of } \\
\text { top management }\end{array}$ & $\begin{array}{l}\text { The final decision on the ap- } \\
\text { pointment of technical character- } \\
\text { istics }\end{array}$ \\
\hline
\end{tabular}

Consider the application of MITHI based on a Decision Support System (DSS) with a three-tier data 
repository. In general, the architecture of an automated identification system specifications (ASID) consists of three levels: data Sources, "data Warehouse" and "data showcase".

The architecture of ASITH at the stage of pre-project research is shown in (Fig. 3).

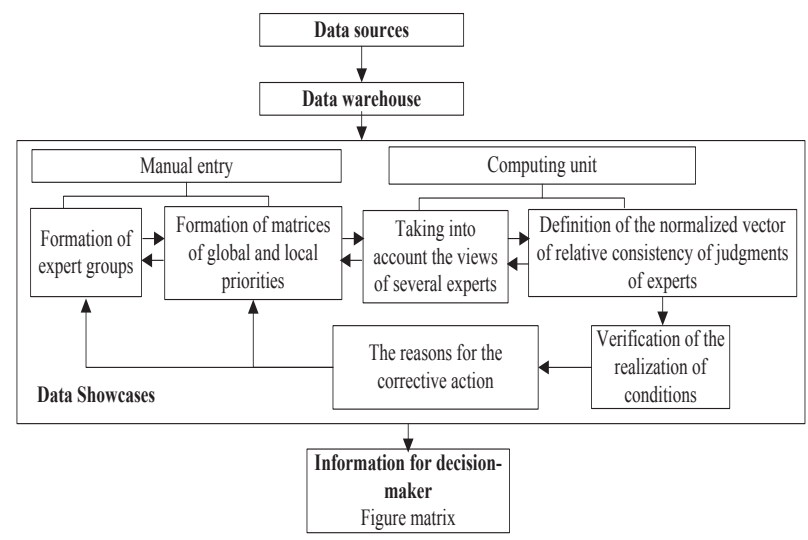

Fig. 3. ASITH architecture at the stage of pre-project research

Block "Data Sources" contains the following information: the external and the internal regulations of the enterprise, structured by types of activities; archival documentation describing the old models of products; database of expert evaluations; results of monitoring of the external environment.

The "Data warehouse" block includes product information structured according to the blocks corresponding to the stages of its life cycle.

The "Data Showcases" block consists of the following modules: the formation of expert groups, the formation of expert solutions, the definition of local and global priorities, the definition of a normal vector and the relative consistency of expert judgments, the causes of inconsistencies and corrective actions.

The "Information for the decision-maker (LPR)" block includes a graphic interpretation of the MITHI that is presented to senior management with the aim of deciding on prioritization of product specifications and the possibility of improving their targets.

"Computing unit", which is providing block, consists of an automated module that includes the following blocks: the system for forming matrices of local and global priorities, the system of determining the index of consistency of experts ' evaluations, the formation of graphical interpretation of MITHI, determining the method of selecting exert groups.

A feature of the proposed technique for identifying technical characteristics of the product is the regulated order of identification of technical characteristics of the product and the adoption of expert decisions [13].

Application of the principles of automation of the pre-project study phase allows to reduce the risk of expert error and the probability of error "human factor" by using a wide range of statistical estimates and contributes to reducing the human, time and financial resources required for the process of identifying the technical characteristics of the product $[14,15]$.

\section{References}

1. E. Taver, Introduction to quality management. Tutorial, 368 p. (2012).

2. O. Gludkin, N. Gorbunov, A Gurov, Iu Zorin, Total quality managment: textbook for high schools, 600 p. (2001)

3. K. Isikava. Japanese quality management methods. 215 p. (1988).

4. T.Grishina, Probabilistic argumentation and decision-making in management of the automated production, Mechatronics, automation, management, №1, pp. 48-52 (2012)

5. T.Grishina, The validity of decision-making in management of the automated production, Vestnik MGTU «Stankin», № 3 (21), pp.70-75 (2012)

6. T. Saati, Decision making with dependence and feedback/Translation from English. Scientific edition board A. Andreichikov, O. Andreichikova, 360 p. (2011)

7. R. Khvastunov, A.Feofanov, V. Korneeva, E. Nakhapetian, Qualimetry in mechanical engineering, 285 p. (2009)

8. V. Korneeva, N. Negrimovskaia, A. Feofanov, The calculation of optimal number of experts and volume data identified by results of preliminary survey, Tekhnologiia mashinostroeniia, № 12, pp. 35-39, (2012).

9. N. Shokhrina, A. Feofanov, Automation of the design stage of production through the application of the methodology of the development of the quality function, Tekhnologiia mashinostroeniia, №5 (155), pp. 89-92. (2015)

10. N. Shokhrina, A. Feofanov, Automated system of determination the priority technical specifications on the designing stage, RIA «Standarty i kachestvo», №3 (945), P. 108 (2016)

11. A. Feofanov, Methods of selection of experts to expert groups, Tekhnologiia mashinostroeniia, №10, pp.58-67 (2008)

12. A. Feofanov, Y. Eleneva, T. Grishina, A. Skhirtladze, N. Negrimovskaia, Participation in organization of production activities of structural divisions of the enterprises of mechanical engineering, textbook for high schools, 144 p. (2014)

13. N. Shokhrina., A. Feofanov, T.Grishina, The basic of the methodology of the substantiation of technical specifications, Vestnik MGTU «Stankin», № 4 (35), pp. 113-116 (2015)

14. V. Mitrofanov, T. Grishina, A. Feofanov, Management of automated technological systems and simulation efficiency when making decisions, Tekhnologiia mashinostroeniia, №8 (158), pp. 43-46 (2015)

15. A. Skhirtladze, V. Voronov, V. Boriskin, Automation of production processes in mechanical engineering: textbook, 600 p. (2013) 